\title{
Tiesību vienpusēji atkāpties no līguma realizēšanas problemātika
}

\author{
Jänis Meija \\ Rīgas Stradiña universitāte, Juridiskā fakultāte, Latvija
}

\section{Kopsavilkums}

Raksta uzdevums ir sniegt ieskatu tiesību vienpusēji atkāpties no līguma realizēšanas problemātikā, kas pastāv, jo Latvijas civiltiesībās līgumu pildī̌anas (pacta sunt servanda) civiltiesību pamatprincipam ir visai maz izṇēmumu.

Rakstā izcelta problēmas praktiskā puse, kas saistās ar pārmērīgu zaudējumu, nevienlīdzīgām pušu attiecībām vai apstākḷ maiṇu. Rakstā analizēts pozitīvs piemērs patērētāju kreditēšanas normatīvais regulējums.

Problēmas novitāti apliecina līgumtiesību starptautiskās unifikācijas tendences, un par tām pieaug publikāciju skaits. Secinot, ka Civillikumā paplašināmas līdzēju tiesības vienpusēji atkāpties no līguma, autors piedāvā attiecīgu likumu grozījumu redakciju.

Atslēgvārdi: līguma saistošais spēks, pacta sunt servanda, tiesības vienpusēji atkāpties no līguma, vienpusēja atkāpšanās no līguma, būtisks līguma pārkāpums.

\section{Raksta mērḳis}

Raksta mērḳis ir, izmantojot analītisko pētījumu metodi un analizējot Latvijas Republikas normatīvo regulējumu un tā praktisko piemērošanu, sniegt ieskatu tiesību vienpusēji atkāpties no līguma realizēšanas problemātikā, kas pastāv, jo Latvijas civiltiesībās līgumu pildī̌anas (pacta sunt servanda) civiltiesību pamatprincipam ir visai maz izṇēmumu.

Izcel̨ot problēmas praktisko pusi, kas saistās ar pārmērīgu zaudējumu, nevienlīdzīgām pušu attiecībām vai apstākḷu maiṇu, kā pozitīvs piemērs rakstā analizēts patērētāju kreditēšanas normatīvais regulējums. Līgumtiesību starptautiskās unifikācijas tendences un par to pieaugošo publikāciju skaits apliecina problēmas šā briža aktualitāti. 
Jānis Meija. Tiesību vienpusēji atkāpties no līguma realizēšanas problemātika

\section{Rezultāti}

Pacta sunt servanda principam ir noteicoša loma Latvijas Republikas Civillikuma [4] normu piemērošanā. Šis princips izteikts Civillikuma [4] 1587. pantā, kas noteic, ka tiesīgi noslēgts līgums uzliek līdzējam pienākumu izpildìt apsolìto, un ne darỉjuma sevišķais smagums, ne arī vēlāk radušās izpildīšanas grūtības nedod vienai pusei tiesību atkāpties no līguma, kaut arī atlīdzinot otrai zaudējumus. Civillikuma [4] 1588. pants pastiprina minēto līdzēja pienākumu, paredzot, ka viena puse nevar atkāpties no līguma bez otras piekrišanas pat tad, ja pēdējā to neizpilda, un tādẹl, ka viña to neizpilda.

Praksē jāsaskaras ar minētā principa realizēšanas problēmām, piemēram, ja otra puse nepilda līguma noteikumus, ir ierobežotas tiesības vienpusēji atkāpties no līguma, kā arī ir apgrūtināta iespēja slēgt citu līgumu par nesaṇemto līguma priekšmetu.

Tāpat Civillikuma [4] 1587. un 1588. panta regulējums ir uzskatāms par netaisnīgu līgumos ar nesamērīgām pušu saistībām un dažos līgumos ar juridiskajām personām, kurām pēc līguma noslēgšanas pasludināts maksātnespējas process.

Tiesības vienpusēji atkāpties no līguma kā pacta sunt servanda principa izṇēmums: pacta sunt servanda principa mērḳis ir civiltiesiskās stabilitātes nodrošināšana, tomēr šo mērḳi nepieciešams sabalansēt ar taisnīguma principu civiltiesiskajās attiecībās, ja būtiski mainījušies apstākḷi, kas ietekmē saistību pildīšanas pienākumu. Slēdzot darījumus, kuros nodibinātās saistības izpildāmas ilgtermiñā, līdzējiem ir iespēja pielīgt saistību izbeigšanas iespēju, piel̦aujot situāciju, kurā sevišḳi izmainās apstākḷi. Puses, slēdzot līgumu, ṇem vērā līguma noslēgšanas brīdī pastāvošos apstākḷus. Tādēl tiesības vienpusēji atkāpties pieḷaujams pamatot vienīgi ar apstākḷiem, kas var iestāties nākotnē.

Latvijas Republikas normatīvajos aktos noteiktās tiesības vienpusēji atkāpties no līguma izpildes un priekšlikumi normatīvā regulējuma uzlabošanai:

Civillikuma [4] 1589. pantā noteikts, ka vienpusēja atkāpšanās no līguma ir piel̦aujama tikai tad, kad tā pamatota ar paša līguma raksturu vai kad to zināmos apstākḷos atḷauj likums, vai arī kad tāda tiesība bijusi noteikti pielīgta.

Civillikums [4] paredz tiesības vienpusēji atkāpties no līguma:

1) sakarā ar darījuma formas neievērošanu (CL 1475. panta otrā daḷa, 1488. panta 3. punkts, 1489. pants);

2) pārmērīga zaudējuma gadījumā nomas un īres tiesiskajās attiecībās (CL 2170. pants);

3) pārāk zema aprēḳina un plāna sagrozī̌sanas gadījumā uzṇēmuma līguma tiesiskajās attiecībās (CL 2229. pants).

Arī citi normatīvie akti regulē tiesības vienpusēji atkāpties no līguma, piemēram, Publisko iepirkumu likuma [7] 67. panta otrās dal̦as 7. punkts paredz, ka iepirkuma līgumā norādāma kārtība, kādā pieḷaujama atkāpšanās no līguma, Patērētāju tiesību aizsardzības likuma [6] 12. panta pirmajā dạ̦ā noteiktās atteikuma tiesības paredz patērētāja tiesības noteiktā termiṇā vienpusēji atkāpties no līguma, Komerclikuma [5] 478. panta otrā daḷa nosaka līdzēju tiesības vienpusēji atkāpties no franšīzes līguma, ja saistību izpilde kḷuvusi pārmērīgi apgrūtinoša objektīvu apstākḷ izmaiṇu dẹḷ. 
Vienpusējas atkāpšanās tiesības no līguma nodalāmas no vienpusēja prasījuma tiesībām tiesas ceḷā prasīt līguma atcelšanu, kas paredzētas, piemēram, Civillikuma [4] 1663. pantā, ja kreditors parādnieka nokavējuma dēl vairs nav ieinteresēts līguma izpildī̌̌anā, tad viṇš var prasît tā atcelšanu.

Civillikuma [4] 2040. pantā paredzētas tiesības izṇēmuma veidā pēc vienas puses prasijuma atcelt pirkuma līgumu, ja viena puse bijusi piedabūta noslēgt līgumu vai nu ar otras l̦aunprātību, vai ar viltu, vai ar spaidiem, pirktās lietas trūkumu dēl, pamatojoties uz blakus nolīgumiem, ar kuriem paturēta atkāpšanās tiesība, un pārmērīgā zaudējuma dēl, ko cieš viena vai otra puse.

Latvijas likumos nav tāda jēdziena "būtisks līguma pārkāpums", taču UNIDROIT Starptautisko komerclīgumu principi, ANO Konvencija par starptautiskajiem preču pirkuma līgumiem un Eiropas līgumu tiesību principi atzīst sarežgijijumu izpausmes, kas tomēr parasti neved uzreiz pie tiesībām atkāpties no līguma.

Atšk রirībā no Latvijas Civillikuma norādītajos aktos ietvertas divas citas risinājumu iespējas:

1) pagarinājuma noteikšana saistības izpildei;

2) sarunas par līguma pārveidošanu, grozišanu $[2,38]$.

Eiropas zinātnieki izstrādā vispārinātus noteikumus, generālklauzulas par līgumu izpildē radušos sarežğijumu atrisināšanu [3, 68].

Tādēḷ, secinot, ka Civillikumā paplašināmas līdzēju tiesības vienpusēji atkāpties no līguma, attiecībā uz aplūkoto problemātiku Latvijas tiesību sistēmā apsverama iespēja Civillikuma 1588. pantu izteikt šādā redakcijā: "Viena puse nevar atkāpties no līguma bez otras piekrišanas pat arī tad, ja pēdējā to neizpilda, izṇemot gadijjumus, ja pēdējā, neizpildot līgumu, būtiski pārkāpj tā noteikumus."

Iepriekšminētā kontekstā raksta turpinājumā tiks analizēts patērētāju kreditēšanas normatīvais regulējums, kas ir pozitīvs piemērs minētās problēmas speciālam regulējumam.

Ministru kabineta 2010. gada 28. decembra noteikumu Nr. 1219 "Noteikumi par patērētāja kreditēšanu" [8] 27. punktā norādīts, ka patērētājam pirms kreditēšanas līguma saistību uzṇemšanās jābūt informētam par sekām, ja netiks veikts maksājums.

Tādējādi, ietverot kreditēšanas līgumā tiesības vienpusēji atkāpties no līguma, pirmkārt, līgumā būtu jānorāda, konkrēti par kādu līguma punkta pārkāpumu piemērojamas tiesības vienpusēji atkāpties no līguma. Otrkārt, patērētājam jāizprot, vai katrā no uzskaitïtajiem gadījumiem, kad līgumā ir paredzētas kredītiestādes tiesības vienpusēji atkāpties no līguma, līgumsaistību izpilde tiek būtiski ietekmēta. Treškārt, patērētāju tiesību aizsardzības kontekstā, piemērojot Patērētāju tiesību aizsardzības likuma [6] 5. pantā noteikto līgumslēdzēju pušu tiesiskās vienlīdzības principu, jāizvērtē, vai kreditors prettiesiski sev par labu nav pielīdzis pārāk plašas un/vai nepamatotas tiesības vienpusēji atkāpties no patērētāju kredītlīguma.

Patērētāju tiesību aizsardzības likuma [6] 6. panta pirmā daḷa nosaka: šādas kreditora pārāk plašas un / vai nepamatotas tiesības vienpusēji atkāpties no patērētāju kredìtlīguma var tikt atzìtas par netaisnīgu līguma noteikumu. 
Lai panāktu, ka patērētāju kredītlīgumā ietvertās prasības kreditora tiesībām vienpusēji atkāpties no patērētāju kredītlīguma ir skaidras un abu līgumslēdzējpušu interesēm atbilstošas, nepieciešams ievērot šādus nosacijumus:

1) tiesībām vienpusēji atkāpties no patērētāja kreditēšanas līguma jābūt konkrēti atrunātām līgumā, atsaucoties uz konkrētiem līguma pārkāpumiem, kas var izsaukt attiecīgu kreditora rīcību;

2) līguma pārkāpumiem jābūt precīzi noteiktiem, tie nedrīkst būt pārlieku plaši piemērojami, lietojot tādus formulējumus kā "jebkuri līguma pārkāpumi” vai "jebkura līguma noteikuma neizpilde".

Ja minētais nav ievērots, tad šādi līgumā ietverti formulējumi ir prettiesiski un nevar būt par pamatu vienpusēji atkāpties no kreditēšanas līguma.

Turklāt jāṇem vērā, ka patērētāju kreditēšanas līgumā jānorobežo nozīmīgi līguma pārkāpumi no maznozīmīgiem. Maznozīmīgi līguma pārkāpumi pēc būtības vispār neiespaido līgumā uzṇemto saistību izpildi. Tādēl, pielīgstot kreditoram tiesības vienpusēji atkāpties no līguma, atsaucoties uz to, ka patēēēājs, saskañā ar līguma noteikumiem, piemēram, nav paziņojis par savas deklarētās dzìvesvietas maiṇu 10 dienu laikā no dzīvesvietas maiṇas brīža, patērētājs tiek nostādìts neizdevīgā stāvoklī attiecībā pret pakalpojuma sniedzēju saskaņā ar Patērētāju tiesību aizsardzības likuma [6] 5. panta otrās daḷas 5. punktu un 6. panta trešās daḷas 1. punktu, un šāds noteikums būtu uzskatāms par netaisnīgu līguma noteikumu.

Savukārt pie būtiskiem pārkāpumiem, kas var ietekmēt nozīmīgas kreditora intereses un var būt par pamatu kreditora tiesībām vienpusēji atkāpties no kreditēšanas līguma, pieskaitāma, piemēram, kredīta atmaksas vai procentu samaksas maksājumu kavēšana līguma saistību izpildi ietekmējošu laika posmu.

Kreditora tiesībām vienpusēji atkāpties no līguma jābūt samērīgām ar patērētāja pieḷauto līguma pārkāpumu. Nav pieḷaujams, ka patēētāja kreditēšanas līgumā tiek pielīgta kreditora tiesība vienpusēji atkāpties no šì līguma, ja, piemēram, savas saistības pret kreditoru nepilda galvotājs, kas galvojis par patēētāja saistībām.

Lìgumā ir jābūt noteiktam, ka pirms kreditors realizē savas līgumā pielīgtās tiesības par vienpusēju atkāpšanos no patēētāja kreditēšanas līguma, viṇam par to jābrīdina patērētājs noteiktā kārtībā un saprātīgā termiņā.

Uzskaitot līguma noteikumos gadijumus, kādos kreditoram ir tiesības vienpusēji atkāpties no līguma, būtu jāṇem vērā fakts, vai patērētājam uzliktais pienākums neierobežo patērētāja likumīgās tiesības. Tāpēc pirms patērētāja kreditēšanas līguma vienpusējas uzteikšanas, kreditoram būtu ieteicams izmantot citus, mazāk patērētāju ietekmējošus līdzekḷus patērētāja pieḷautā līguma pārkāpuma novēršanai.

Bez patērētāju kreditēšanas normatīvā regulējuma attīstǐšanas, likumdevējam būtu jāturpina Civillikuma modernizācija, kurā likumdevējam jāṇem vērā līgumtiesību tiesību unifikācijas dokumenti - priekšlikums regulai "Par vienotiem Eiropas tirdzniecības noteikumiem" (CESL), kopējā model̦a projekts (Draft Common Frame of Reference (DCFR)) un citu starptautisko tiesību unifikācijas dokumenti [1]. Tomēr šīm 
izmain̄ām un to piemērošanai Latvijas Republikas tiesu praksē jābūt pārdomātai un iepriekš pietiekami publiski apspriestai, jo pirmskara Latvijas Republikas likumdevēja iedibinātai civiltiesisko attiecību stabilitātei ir neatsverama nozīme Civillikuma normu piemērošanā.

\section{Enforcement Problems of the Right to withdraw from a Contract Unilaterally}

\section{Abstract}

The aim of the article is to provide an insight into problems of the right to withdraw from a contract unilaterally that exist because the Civil Law of Latvia has very few exceptions to the basic principle of contract filling (pacta sunt servanda).

The article highlights the practical side of the problem due to excessive loss, unequal relationship between the parties or a change of circumstances. Legal regulation of consumer creditation is analyzed in the article as a positive example.

The international unification trends of the Contract Law and the growing number of publications confirm the novelty of the problem. Concluding that the rights of parties to withdraw from a contract unilaterally should be extended in the Civil Code, the author proposes amendments to the relevant version of the laws.

Keywords: change of circumstances, pacta sunt servanda, right to withdraw from a contract unilaterally.

\section{Literatūra}

1. Torgāns, K. Saistību tiesības. I daḷa. Mācību grāmata. Rīga: Tiesu namu aǵentūra, 2006, 68. lpp.

2. Kalniṇa, V. Tiesības vienpusēji atkāpties no pirkuma līguma un to attīstīšana Civillikumā. Jurista Vārds, Nr. 40 (842), 2014. g. 14. okt.

3. Torgāns, K. Civillikuma Saistību tiesību daḷas modernizācijas nepieciešamība un aktuālo privāttiesiskā regulējuma tendenču (UNIDROIT, ELTP) iespējamā ietekme uz Civillikuma Saistību tiesību daḷas modernizāciju. Zinātnisks pētījums. Rīga: Zvērinātu advokātu birojs "Lejiňš, Torgāns un Partneri", 2007, 38. lpp.

4. Civillikums. [1937. g. 28. janv.] Valdības Vēstnesis, Nr. 41, 1937. g. 20. febr.

5. Komerclikums. [2000. g. 13. apr.] Latvijas Vēstnesis, Nr. 185/160 (2069/2071).

6. Patērētāju tiesību aizsardzības likums. [1999. g. 18. marts.] Latvijas Vēstnesis, Nr. 104/15 (1564/1565).

7. Publisko iepirkumu likums. [2006. g. 6. apr.] Latvijas Vēstnesis, Nr. 65 (3433).

8. Ministru kabineta 2010. gada 28. decembra noteikumi Nr. 1219 "Noteikumi par patērētāja kreditēšanu". Latvijas Vēstnesis, Nr. 2 (4400). 